\title{
Mutations Affecting Penicillin-binding Proteins 2a, 2b and 3 in Bacillus subtilis Alter Cell Shape and Peptidoglycan Metabolism
}

\author{
By MOHAMED SHOHAYEB AND IAN CHOPRA* \\ Department of Microbiology, The Medical School, University of Bristol, Bristol BS8 ITD, UK
}

(Received 12 January 1987)

\begin{abstract}
Bacillus subtilis mutants with altered penicillin-binding proteins (PBPs), or altered expression of PBPs, were isolated by screening for changes in susceptibility to $\beta$-lactam antibiotics. Mutations affecting only PBPs $2 a, 2 b$ and 3 were isolated. Cell shape and peptidoglycan metabolism were examined in representative mutants. Cells of a PBP 2a mutant (UB8521) were usually twisted whereas PBP 2b (UB8524) and 3 (UB8525) mutants produced helices, particularly after growth at $41^{\circ} \mathrm{C}$. The PBP 2a mutant (UB8521) had a higher peptidoglycan synthetic activity than its parent strain whereas the opposite applied to the PBP 2b mutant UB8524. The PBP 3 mutant (UB8525) had a similar peptidoglycan synthetic activity to that of the parent strain when grown at $37^{\circ} \mathrm{C}$, but $40 \%$ higher activity after growth at $41{ }^{\circ} \mathrm{C}$. The PBP 2a mutant (UB8521) exhibited the same wall thickening activity as the parent, but the PBP $2 b$ and 3 mutants (UB8524 and UB8525) were partially defective in this respect. The changes in the susceptibility of PBP 2a, 2b and 3 mutants to $\beta$-lactam antibiotics imply that these PBPs are killing targets, consistent with the fact that these PBPs are also important for shape determination and peptidoglycan synthesis.
\end{abstract}

\section{INTRODUCTION}

Bacteria which synthesize peptidoglycan contain a set of cytoplasmic membrane proteins that bind penicillin covalently (Spratt, 1983; Waxman \& Strominger, 1983; Frere \& Joris, 1985). These proteins, known as penicillin-binding proteins (PBPs), perform the final stages of peptidoglycan synthesis. The high $M_{\mathrm{r}}$ PBPs are usually essential for bacterial cell elongation, septum formation and shape determination. They are also the killing targets for $\beta$-lactam antibiotics since their inhibition leads to cell death and lysis (Spratt, 1983; Waxman \& Strominger, 1983).

Five PBPs were originally identified in Bacillus subtilis which were later further resolved into eight PBPs using improved techniques (Blumberg \& Strominger, 1972; Klepp \& Strominger, 1979). Although $B$. subtilis was the first organism in which multiple PBPs were demonstrated, the killing target and the role of PBPs in shape determination and peptidoglycan synthesis have not yet been thoroughly examined in this organism (Waxman \& Strominger, 1983). Some preliminary attempts have been made to identify which PBPs are killing targets in $B$. subtilis. Horikawa \& Ogawara (1980) examined the affinity of some $\beta$-lactams for the PBPs of $B$. subtilis and Buchanan \& Strominger (1976) isolated carbenicillin resistant mutants on the basis that the mutants might be modified in one or more essential target PBPs. In both cases PBP 2 was identified as a killing target (Horikawa \& Ogawara, 1980; Buchanan \& Strominger, 1976). When PBP 2 was resolved into proteins $2 a$ and $2 b$, the former was identified as a killing target (Klepp \& Strominger, 1982), but nevertheless PBP 2b was not excluded as another possible killing target (Waxman \& Strominger, 1983). Even less is known about the role of $B$. subtilis PBPs in shape determination and peptidoglycan synthesis. However, examination of the

Abbreviations: NTG, $N$-methyl- $N^{\prime}$-nitro- $N$-nitrosoguanidine; PBP, penicillin-binding protein. 
pattern of PBPs during spore germination has suggested that PBP 2a and PBP 2b are involved in vegetative cell elongation and septum formation respectively (Neyman \& Buchanan, 1985).

For further examination of PBPs in $B$. subtilis we isolated $N$-methyl- $N^{\prime}$-nitro$N$-nitrosoguanidine (NTG)-induced mutants defective in PBPs 2a, 2b, and 3. These mutants enabled us to examine the role of these PBPs in shape determination and peptidoglycan synthesis, thereby indicating which PBPs are likely killing targets for $\beta$-lactam antibiotics. Our results suggest that PBPs $2 \mathrm{a}, 2 \mathrm{~b}$ and 3 are important for the growth of $B$. subtilis and therefore are killing targets for $\beta$-lactams.

\section{METHODS}

Bacteria. B. subtilis NCIB 10106 (trp) (Shivakumar et al., 1979) and various NTG-induced mutants derived from it were used. The mutants of NCIB 10106 were (PBP defect in parenthesis) UB8521 (2a), UB8522 (2a), UB8523 (2a), UB8524 (2b) and UB8525 (3). Each of these mutants was derived specifically for this study.

Chemicals. Benzyl[ $\left.{ }^{14} \mathrm{C}\right]$ penicillin (potassium salt, $50 \mathrm{mCi} \mathrm{mmol}^{-1}, 1.85 \mathrm{GBq} \mathrm{mmol}^{-1}$ ) and $N$-acetyl-D- $\left[{ }^{14} \mathrm{C}\right]-$ glucosamine (GlcNAc) $\left(52 \mathrm{mCi} \mathrm{mmol}^{-1}, 1.92 \mathrm{GBq} \mathrm{mmol}^{-1}\right)$ were purchased from Amersham.

Growth media. L-broth comprised, $\mathrm{g}^{-1}:$ Bacto tryptone (20); Difco yeast extract (10) and glucose (10) adjusted to $\mathrm{pH} 7 \cdot 2$. L-Agar was prepared by adding Difco Bacto Agar $(1.65 \%$, w/v) to L-Broth.

Isolation of cytoplasmic membranes. Cultures were grown (routinely at $30^{\circ} \mathrm{C}$ ) to late exponential phase with aeration in L-broth. Bacteria were harvested and suspended in PMP buffer ( 50 mM-sodium phosphate, $\mathrm{pH} 7.5$, $10 \mathrm{mM}-\mathrm{MgCl}_{2}, \quad 100 \mu \mathrm{M}$-phenylmethylsulphonyl fluoride). Lysozyme $\left(500 \mathrm{mg} \mathrm{ml}^{-1}\right)$ and dithiothreitol $\left(400 \mu \mathrm{g} \mathrm{m}^{-1}\right)$ were added and the cells incubated at $30^{\circ} \mathrm{C}$ for $30 \mathrm{~min}$ before sonication (Dawe Soniprobe: $5 \mathrm{~A}$, with $20 \mathrm{~s}$ treatments at $4^{\circ} \mathrm{C}$ ). Debris was removed by low speed centrifugation $\left(4^{\circ} \mathrm{C}, 600 \mathrm{~g}, 15 \mathrm{~min}\right)$ and the cytoplasmic membranes in the supernatant were collected by ultracentrifugation $\left(4^{\circ} \mathrm{C}, 60000 \mathrm{~g}, 1 \mathrm{~h}\right)$. The cytoplasmic membranes were washed twice with PMP buffer, suspended in $50 \mathrm{mM}$-phosphate buffer $\mathrm{pH} 7$ to a concentration of $10 \mathrm{mg}$ protein $\mathrm{ml}^{-1}$ and stored at $-20^{\circ} \mathrm{C}$ prior to further use.

Protein determination. Protein was determined using the Folin-Ciocalteu reagent according to the procedure of Herbert et al. (1971).

Detection of PBPs. Membranes were treated for $10 \mathrm{~min}$ with benzyl[ $\left.{ }^{14} \mathrm{C}\right]$ penicillin $\left(50 \mathrm{mCi} \mathrm{mmol}^{-1}, 30 \mu \mathrm{g} \mathrm{ml}^{-1}\right.$ final concentration) as described by Spratt (1977). Membranes were usually exposed to labelled penicillin at $37^{\circ} \mathrm{C}$, but other temperatures (described in the text) were sometimes used. The reaction was terminated by the addition of an equal volume of SDS buffer ( $0.2 \mathrm{M}-\mathrm{Tris} / \mathrm{HCl}, \mathrm{pH} 7 ; 3 \%(\mathrm{w} / \mathrm{v}) \mathrm{SDS} ; 30 \%(\mathrm{v} / \mathrm{v})$ glycerol; $1 \mathrm{mg}$ unlabelled penicillin $\mathrm{ml}^{-1} ; 0.125 \mathrm{M}$-2-mercaptoethanol) followed by immediate heating $\left(100^{\circ} \mathrm{C}, 5 \mathrm{~min}\right)$. PBPs were separated by slab gel electrophoresis (Suzuki et al., 1978) and labelled proteins were detected by fluorography (Chamberlin, 1979).

Isolation of mutants. B. subtilis NCIB 10106 was mutagenized with NTG as described by Adelberg et al. (1965). Cells hypersensitive or resistant to clavulanic acid or cefotaxime were selected by replica plating. The PBP profiles of these potential mutants were examined to establish whether they were genuine PBP mutants.

Isolation of revertants from PBP mutants. PBP mutants were found to be defective in sporulation (M. Shohayeb \& I. Chopra, unpublished). Revertants were therefore isolated on the basis of restoration of their ability to produce normal spores. Strains were cultured on plates containing sporulation medium (per $100 \mathrm{ml}$ : Difco Heart Infusion Agar, $4 \mathrm{~g} ; \mathrm{MnCl}_{2} .4 \mathrm{H}_{2} \mathrm{O}, 0.5 \mathrm{mg} ; \mathrm{FeSO}_{4} .7 \mathrm{H}_{2} \mathrm{O}, 0.5 \mathrm{mg} ; \mathrm{MgSO}_{4} .7 \mathrm{H}_{2} \mathrm{O}, 4.8 \mathrm{mg} ; \mathrm{CaCl}_{2}, 12.6 \mathrm{mg}$ ) and left for a week. Spores that escaped autolysis and were resistant to chloroform were transferred to another plate to promote cycles of germination and further sporulation. Strains (i.e. potential PBP revertants) that were regularly able to sporulate were checked for their PBP profiles.

Scanning electron microscopy. Bacteria growing in L-broth were fixed by the addition of glutaraldehyde $(2.5 \%$, $\mathrm{v} / \mathrm{v}$ ) in $0.1 \mathrm{M}$-sodium cacodylate buffer ( $\mathrm{pH} 7$ ). After $30 \mathrm{~min}$ the fixed bacteria were concentrated by filtration through a $0.4 \mu \mathrm{m}$ cellulose acetate filter $(13 \mathrm{~mm}$ diameter, Sterilin) and washed with $0.1 \mathrm{M}$-cacodylate buffer (pH 7). Samples were dehydrated by soaking for $10 \mathrm{~min}$ in a series of ethanol solutions of increasing concentration, ranging from $30 \%$ to $100 \%(\mathrm{v} / \mathrm{v})$. Dehydration with ethanol was followed by critical-point drying using carbon dioxide. Samples were sputter-coated with platinum and viewed with a Philips 501 scanning electron microscope.

Determination of peptidoglycan synthetic activity. Bacteria were grown for several generations in L-broth supplemented with $1 \mu \mathrm{Ci}\left[{ }^{14} \mathrm{C}\right] \mathrm{GicNAc} \mathrm{ml}{ }^{-1}$ to achieve steady-state labelling of peptidoglycan. Incorporation of radioactivity into hot TCA-precipitable material was determined according to the procedure of Mertens \& Reeve (1977). Incorporation data were standardized by expressing the results as radioactivity incorporated per $\mathrm{OD}_{600}$ unit of bacteria. Under the labelling conditions employed, approximately $3.0 \times 10^{5} \mathrm{c}$.p.m. of $\left[{ }^{14} \mathrm{C}\right] \mathrm{GlcNAc}$ were incorporated (ml culture) ${ }^{-1}$ when the parent strain NCIB 10106 was grown from 0.25 to $0.75 \mathrm{OD}_{600}$ units at $37^{\circ} \mathrm{C}$. Growth of NCIB 10106 at $41{ }^{\circ} \mathrm{C}$ led to incorporation values of about $3.5 \times 10^{5}$ c.p.m. ml ${ }^{-1}$.

Wall thickening. Wall thickening activity was determined by following the incorporation of $\left[{ }^{14} \mathrm{C}\right] \mathrm{GlcNAc}$ into hot TCA-precipitable material according to the procedure of Mertens \& Reeve (1977), in which bacteria (in 
L-broth) were exposed to chloramphenicol $\left(150 \mu \mathrm{g} \mathrm{m}^{-1}\right)$ prior to labelling. Under the labelling conditions employed, suspensions of NCIB 10106 at $0.25 \mathrm{OD}_{600}$ units incorporated about $9 \times 10^{4}$ c.p.m. of $\left[{ }^{14} \mathrm{C}\right] \mathrm{GlcNAc}$ $\mathrm{ml}^{-1}$ after incubation for $30 \mathrm{~min}$ at $37^{\circ} \mathrm{C}$. At $41{ }^{\circ} \mathrm{C}$, the value was typically $1.2 \times 10^{5}$ c.p.m. ml ${ }^{-1}$ for strain NCIB 10106.

Determination of peptide cross-linking in peptidoglycan. Cultures were labelled with $\left[{ }^{14} \mathrm{C}\right] \mathrm{GlcNAc}$ as described for the determination of peptidoglycan synthetic activity. Bacteria were then extracted with hot TCA (Mertens \& Reeve, 1977) and the acid precipitates were washed in water and resuspended in ammonium acetate (0.1 M) containing pronase $\left(10 \mu \mathrm{g} \mathrm{ml}^{-1}\right)$. Samples were incubated at $37^{\circ} \mathrm{C}$ for $12-15 \mathrm{~h}$ and then heated to $100{ }^{\circ} \mathrm{C}$ for $5 \mathrm{~min}$. After cooling to room temperature, RNAase and DNAase (each at $20 \mu \mathrm{g} \mathrm{ml}^{-1}$ ) were added, and the reaction mixtures incubated for $6 \mathrm{~h}$ at $37^{\circ} \mathrm{C}$. Insoluble material (peptidoglycan) was washed and resuspended in water $(0.84 \mathrm{ml})$. Saturated solutions of sodium bicarbonate $(0.34 \mathrm{ml})$ and acetic anhydride $(0.37 \mathrm{ml})$ were added and the mixtures incubated for $2 \mathrm{~h}$ at $37^{\circ} \mathrm{C}$ to acetylate peptidoglycan. Acetylated peptidoglycan was washed with water and resuspended in $0.1 \mathrm{M}$-ammonium acetate $(1 \mathrm{ml})$ containing lysozyme $\left(10 \mathrm{mg} \mathrm{ml}^{-1}\right)$ and chloramphenicol $\left(2 \mathrm{mg} \mathrm{ml}^{-1}\right)$. Chloroform $(5 \mu \mathrm{l})$ was added and the reaction mixtures were incubated for $12-15 \mathrm{~h}$ at $37^{\circ} \mathrm{C}$. Lysozyme digests were heated $\left(100^{\circ} \mathrm{C}, 3 \mathrm{~min}\right)$, insoluble debris was removed by centrifugation and the supernatants were lyophilized. Peptidoglycan fragments in the lyophilized material were separated by descending paper chromatography $(20 \mathrm{~h}$, Whatman $3 \mathrm{MM}$ paper) using the upper phase of a butan-1-ol/acetic acid/water (4:1:5, by vol.) solvent system (Mirelman et al., 1976). Radioactive spots were located by autoradiography and the activity of each region was quantified by scintillation spectroscopy after excision of the relevant spot from the dried chromatogram.

Determination of MICs. L-agar plates containing various concentrations of each $\beta$-lactam were inoculated with about 50 bacterial cells. The minimum concentration of $\beta$-lactam which prevented colony formation after incubation for $24 \mathrm{~h}$ at $30^{\circ} \mathrm{C}, 37^{\circ} \mathrm{C}$ or $41^{\circ} \mathrm{C}$ was taken as the MIC.

\section{RESULTS}

\section{Selection of mutants}

NTG treated cultures of $B$. subtilis NCIB 10106 were screened at $41{ }^{\circ} \mathrm{C}$ for mutants with altered susceptibility (resistance or hypersensitivity) to selected $\beta$-lactam antibiotics. Many potential PBP mutants were obtained by this means. Preliminary experiments established that only five of these had altered PBPs. These are described more fully below.

\section{PBPs of mutant strains}

Three mutants defective in PBP 2a (strains UB8521, UB8522 and UB8523) were isolated. The PBP 2a of strain UB8521 was temperature sensitive in its ability to bind labelled penicillin since it bound penicillin normally at $30^{\circ} \mathrm{C}$ (Fig. 1, lane 2) and $37^{\circ} \mathrm{C}$ (data not shown), but failed to bind it at $41{ }^{\circ} \mathrm{C}$ (Fig. 1, lane 4). On the other hand, strains UB8522 and UB8523 had altered PBP 2as which migrated faster than the normal PBP 2a of the parent strain during gel electrophoresis (Figs 2 and 3). Mutant strain UB8524 possessed an altered PBP $2 b$ which also migrated faster than the wild-type protein during gel electrophoresis (Fig. 4). Only trace amounts of PBP 3 were detected in membranes from strain UB8525 compared to the parent strain NCIB 10106 (Fig. 5). This applied whether the penicillin binding experiments were done at $30^{\circ} \mathrm{C}, 37^{\circ} \mathrm{C}$, or $41^{\circ} \mathrm{C}$. Fig. 5 compares the profiles of strains NCIB 10106 and UB8525 when the binding was done at $37^{\circ} \mathrm{C}$.

\section{Sensitivity of mutants to $\beta$-lactams}

The PBP mutants described above were screened on the basis of altered susceptibility to $\beta$ lactam antibiotics, particularly clavulanic acid and cefotaxime. Their response to these and other $\beta$-lactams at $30^{\circ} \mathrm{C}, 37^{\circ} \mathrm{C}$ and $41^{\circ} \mathrm{C}$ was subsequently examined in more detail. The mutants were either hypersensitive or resistant to most of the antibiotics at all temperatures tested. Table 1 shows the susceptibility of the mutants to some $\beta$-lactams at $37^{\circ} \mathrm{C}$.

The PBP 2a mutant UB8521 was initially isolated as hypersensitive to clavulanic acid, but it was also subsequently found to be hypersensitive to other $\beta$-lactam antibiotics (Table 1 ). In contrast, PBP 2a mutant strains UB8522 and UB8523 were resistant to $\beta$-lactams (Table 1). The PBP 2b mutant UB8524 was isolated as sensitive to clavulanic acid and it was subsequently found to be hypersensitive to cefotaxime and cefuroxime. However, its susceptibility to some 


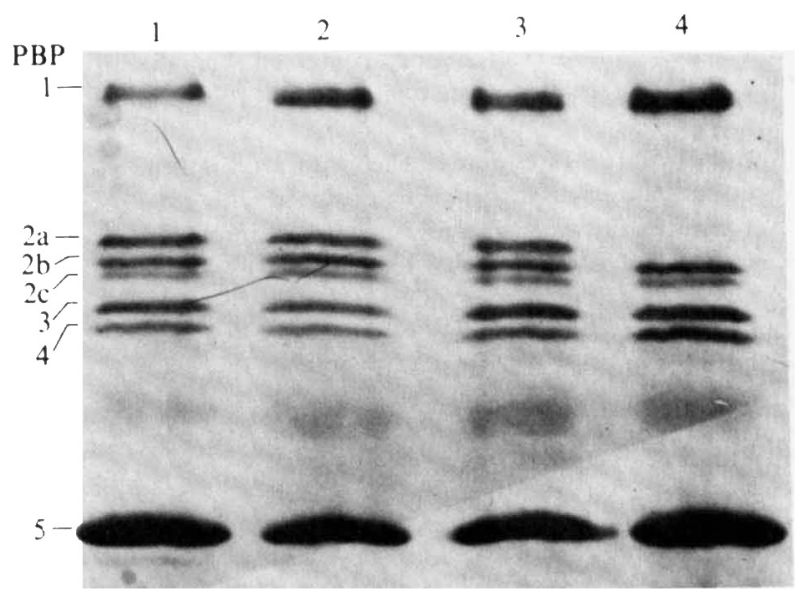

Fig. 1

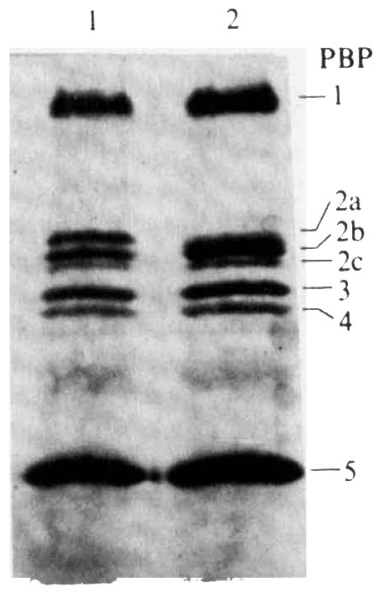

Fig. 2

Fig. 1. PBPs in the membrane of the PBP 2a mutant UB8521. PBPs were detected by fluorography following separation of proteins by PAGE as described in Methods. Labelling with benzyl[ $\left.{ }^{14} \mathrm{C}\right]-$ penicillin was done at $30^{\circ} \mathrm{C}$ (lanes 1 and 2 ) or $41^{\circ} \mathrm{C}$ (lanes 3 and 4). Lanes 1 and 3, parent strain; 2 and 4 , PBP 2a mutant UB8521.

Fig. 2. PBPs in the membrane of the PBP 2a mutant UB8522. PBPs were detected by fluorography following separation of proteins by PAGE as described in Methods. Labelling with benzyl[ $\left.{ }^{14} \mathrm{C}\right]-$ penicillin was done at $37^{\circ} \mathrm{C}$. Lane 1, parent strain; lane 2, PBP 2a mutant UB8522.

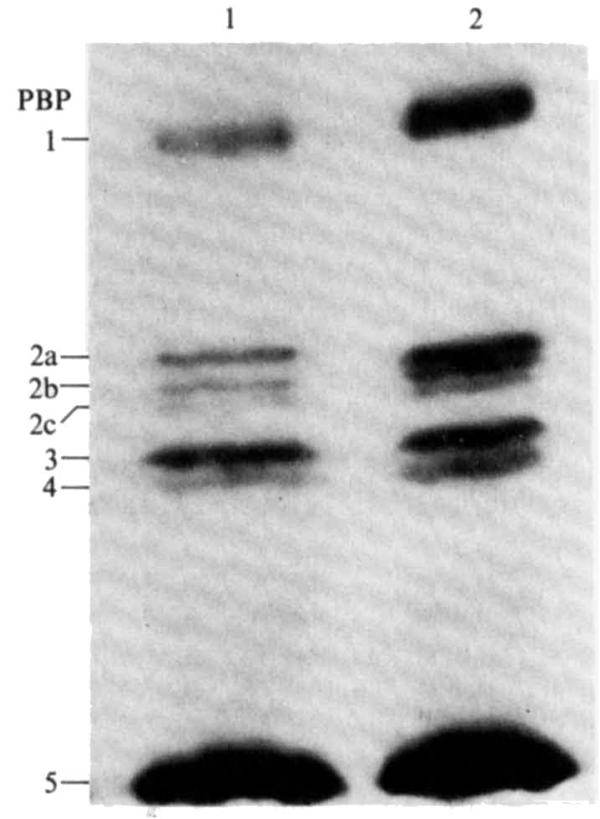

Fig. 3

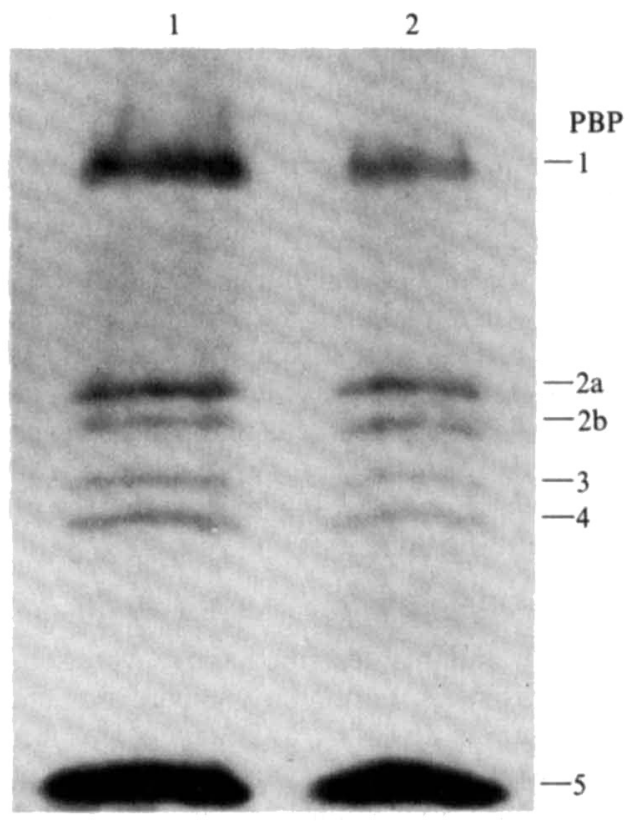

Fig. 4

Fig. 3. PBPs in the membrane of the PBP 2a mutant UB8523. The PBPs were labelled and detected as described in the legend to Fig. 2. Lane 1, parent strain; lane 2, PBP 2a mutant UB8523.

Fig. 4. PBPs in the membrane of the PBP 2b mutant UB8524. The PBPs were labelled and detected as described in the legend to Fig. 2. Lane 1, parent strain; lane 2, PBP 2 b mutant UB8524. 


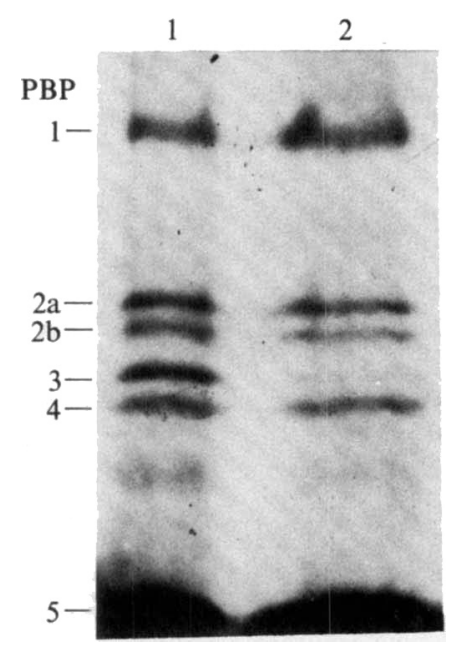

Fig. 5. PBPs in the membrane of the PBP 3 mutant UB8525. The PBPs were labelled and detected as described in the legend to Fig. 2. Lane 1, parent strain; lane 2, PBP 3 mutant UB8525.

Table 1. Susceptibility of B. subtilis strains to $\beta$-lactams at $37^{\circ} \mathrm{C}$

Antibiotic
Ampicillin
Benzylpenicillin
Cefotaxime
Cefuroxime
Cephalexin
Clavulanic acid
Cloxacillin
Mecillinam
Methicillin

\begin{tabular}{cccccc}
\hline NCIB 10106 & UB8521 & UB8522 & UB8523 & UB8524 & UB8525 \\
0.02 & 0.01 & 0.04 & 0.04 & 0.02 & 0.01 \\
0.02 & 0.01 & 0.04 & 0.04 & 0.02 & 0.01 \\
0.4 & 0.1 & 0.8 & 0.8 & 0.8 & 0.1 \\
0.4 & 0.04 & 1.6 & 1.6 & 0.8 & 0.1 \\
0.1 & 0.025 & 0.2 & 0.4 & 0.1 & 0.05 \\
6.4 & 0.4 & 12.8 & 12.8 & 3.2 & 1.6 \\
0.2 & 0.05 & 0.4 & 0.8 & 0.2 & 0.1 \\
4 & 2 & 8 & 16 & 4 & 1 \\
0.1 & 0.025 & 0.2 & 0.2 & 0.1 & 0.025
\end{tabular}

other $\beta$-lactam antibiotics was unaltered (Table 1). The PBP 3 mutant UB8525, isolated on the basis of its hypersensitivity to cefotaxime, was later found to be hypersensitive to other $\beta$ lactams (Table 1).

\section{Morphology of the mutants}

Mutants UB8522 and UB8523 (both PBP 2a mutants) exhibited normal cell shapes at all growth temperatures (data not shown). However, mutants UB8521 (PBP 2a), UB8524 (PBP 2b) and UB8525 (PBP 3) showed morphological changes when they were examined by scanning electron microscopy (Figs 6 and 7). Cells of the PBP 2a mutant UB8521 were usually twisted and occasionally helical in shape at all growth temperatures; Figs $6(b)$ and $7(b)$ show the mutant grown at $37^{\circ} \mathrm{C}$ and $41^{\circ} \mathrm{C}$ respectively. Cells of the PBP $2 b$ mutant UB8524 formed distorted helices and the effect was particularly marked at $41^{\circ} \mathrm{C}$ (Figs $6 c$ and $7 c$ ). The mutant defective in PBP 3 (UB8525) formed helices, but the extent of coiling was generally less than that exhibited by the PBP $2 \mathrm{~b}$ mutant. Figs $6(d)$ and $7(d)$ show cells of strain UB8525 grown respectively at $37^{\circ} \mathrm{C}$ and $41^{\circ} \mathrm{C}$. Generally, the growth rates of all mutants were slower than the parent strain, especially at high temperatures (data not shown).

\section{Peptidoglycan synthetic activity}

Peptidoglycan synthetic activities in the mutant strains UB8521, UB8524 and UB8525 were compared with the parent strain NCIB 10106. Peptidoglycan synthesis in the PBP 2a mutant 

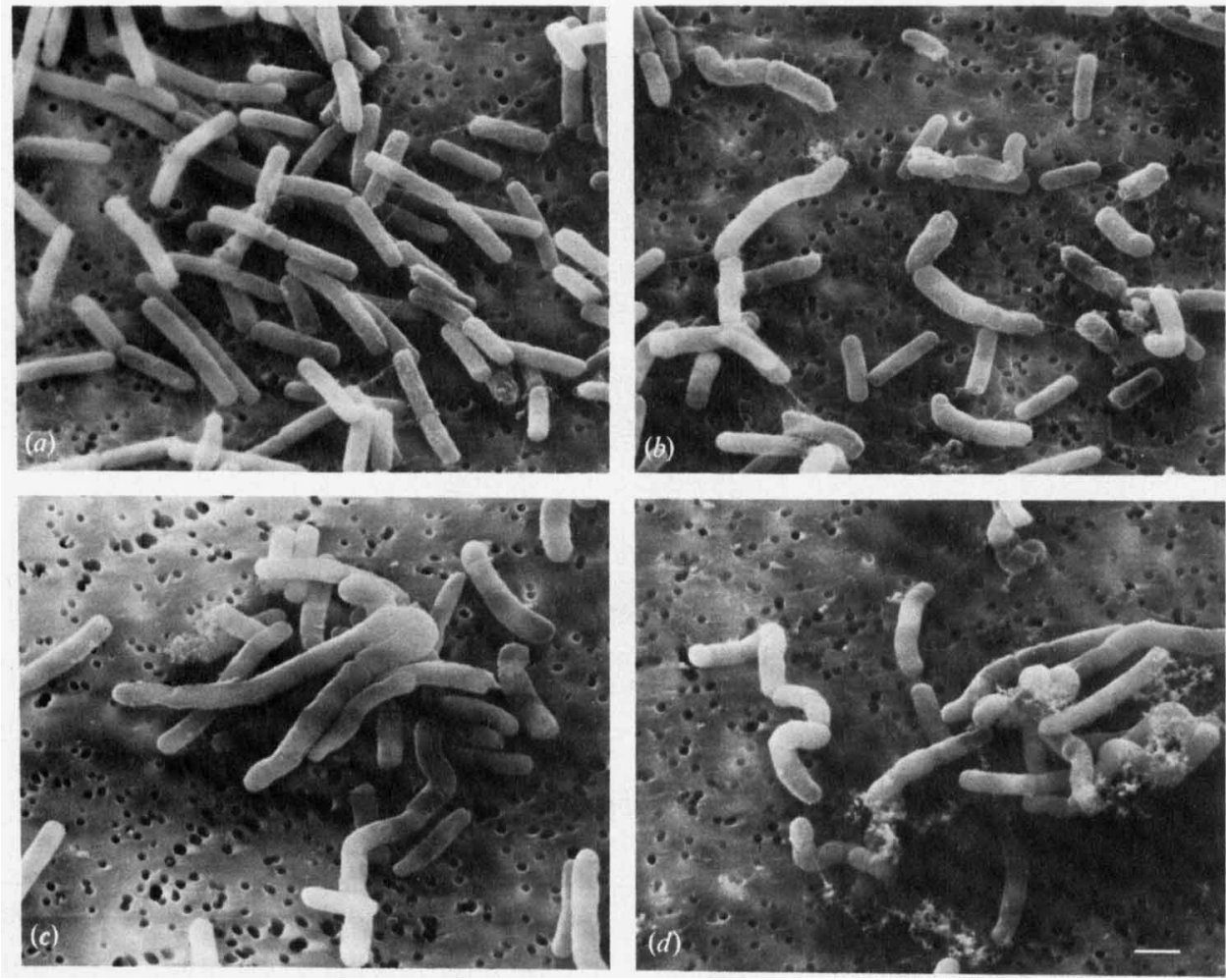

Fig. 6. Scanning electron microscopy of wild-type and PBP mutants of B. subtilis grown at $37^{\circ} \mathrm{C}$ in L-broth. (a) Parent strain NCIB 10106; (b) PBP 2a mutant UB8521; (c) PBP 2b mutant UB8524; (d) PBP 3 mutant UB8525. Bar, $1 \mu \mathrm{m}$.

\section{Table 2. Peptidoglycan synthetic activities of PBP mutants of B. subtilis}

Bacteria were grown in L-broth for several generations in the presence of $\left[{ }^{14} \mathrm{C}\right] \mathrm{GlcNAc}$ as described in Methods. The $\mathrm{OD}_{600}$ of the culture was followed in a separate reaction mixture to standarize the data as radioactivity incorporated per $\mathrm{OD}_{600}$ unit of bacteria. Cells were treated with hot $5 \% \mathrm{TCA}$ and acid insoluble radioactivity was counted after washing the precipitates. Values are means \pm SD for duplicate experiments with three replicas in each case.

$\begin{array}{cccc}\text { Strain } & \begin{array}{c}\text { PBP } \\ \text { defect }\end{array} & \overbrace{37^{\circ} \mathrm{C}}^{\begin{array}{c}\text { Peptidoglycan synthetic activity } \\ \text { (relative to parent strain) at }\end{array}} \\ \text { UB8521 } & 2 \mathrm{a} & 1.56 \pm 0.02 & 41^{\circ} \mathrm{C} \\ \text { UB8524 } & 2 \mathrm{~b} & 0.24 \pm 0.09 & 1.49 \pm 0.14 \\ \text { UB8525 } & 3 & 1.14 \pm 0.25 & 0.28 \pm 0.80 \\ & & \end{array}$

UB8521 was greater than in the parent strain at both $37^{\circ} \mathrm{C}$ and $41^{\circ} \mathrm{C}$ (Table 2). In contrast, the peptidoglycan synthetic activity of the PBP $2 \mathrm{~b}$ mutant UB8524 was about $25 \%$ of the parent strain at both high and low temperatures (Table 2). The mutant altered in PBP 3 (UB8525) had a peptidoglycan synthetic activity similar to the parent strain at $37^{\circ} \mathrm{C}$, but a higher activity at $41^{\circ} \mathrm{C}$ than the parent strain grown at the same temperature (Table 2).

\section{Wall thickening}

When protein synthesis is stopped in a Gram-positive bacterium by the addition of a translation inhibitor such as chloramphenicol, wall thickening occurs (Shockman, 1965). The parent strain NCIB 10106 and the PBP mutants UB8521, UB8524 and UB8525 were incubated 

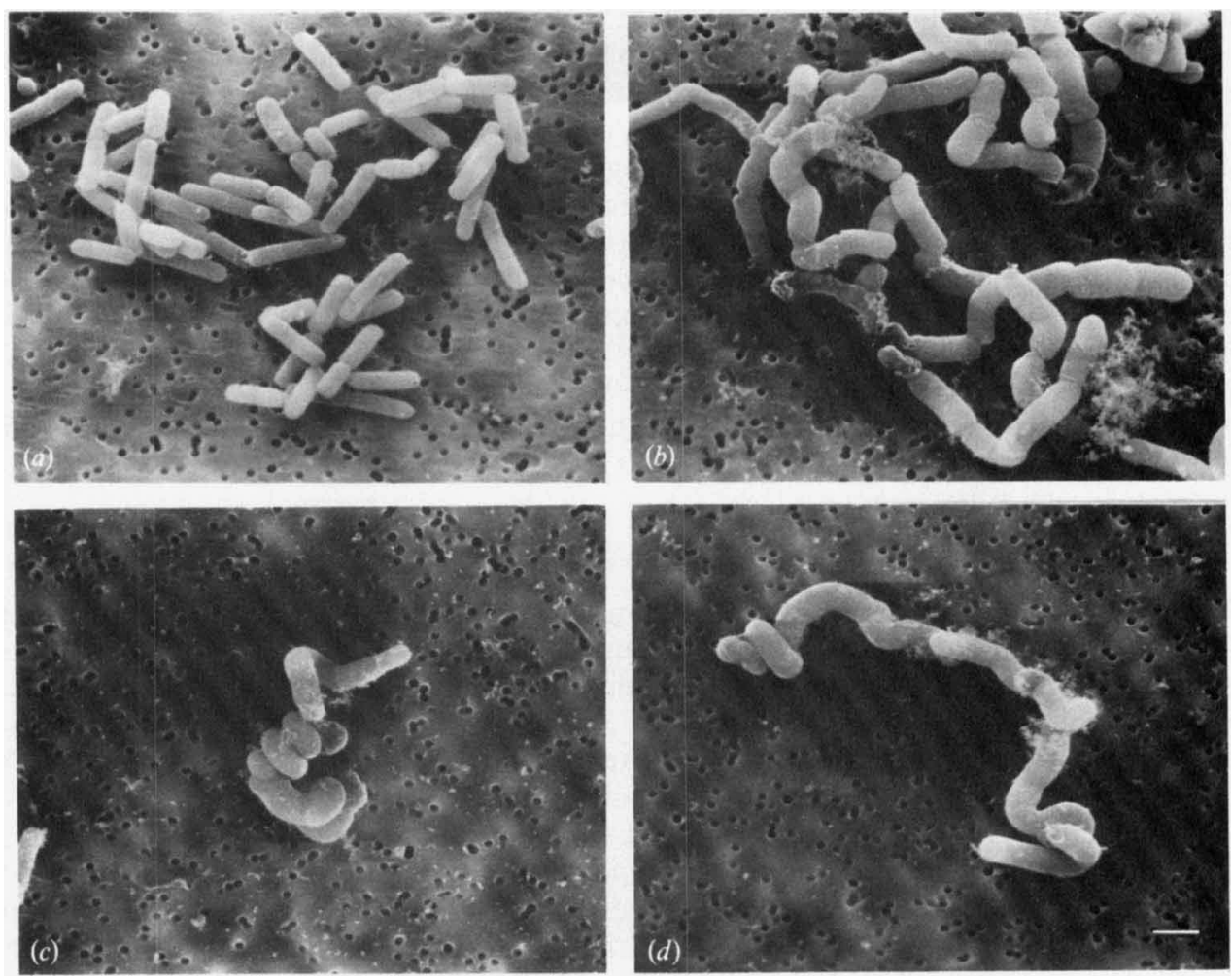

Fig. 7. Scanning electron microscopy of wild-type and PBP mutants of $B$. subtilis grown at $41^{\circ} \mathrm{C}$ in L-broth. (a) Parent strain NCIB 10106; (b) PBP 2a mutant UB8521; (c) PBP 2b mutant UB8524; (d) PBP 3 mutant UB8525. Bar, $1 \mu \mathrm{m}$.

\section{Table 3. Wall thickening in PBP mutants of $B$. subtilis}

Bacteria growing exponentially were adjusted to an $\mathrm{OD}_{600}$ of $0 \cdot 2$. Chloramphenicol $\left(150 \mu \mathrm{g} \mathrm{ml}^{-1}\right)$ was added, followed, after $30 \mathrm{~min}$, by $\left[{ }^{14} \mathrm{C}\right] \mathrm{GlcNAc}$ as described in Methods. After a further $30 \mathrm{~min}$, samples were taken into hot TCA. Hot TCA precipitates were washed several times before the radioactivity was counted. Values are means $\pm \mathrm{SD}$ for duplicate experiments with three replicas in each case.

\begin{tabular}{cccc} 
Strain & $\begin{array}{c}\text { PBP } \\
\text { defect }\end{array}$ & \multicolumn{3}{c}{$\begin{array}{c}\text { Wall thickening activity } \\
\text { (relative to parent strain) at }\end{array}$} \\
\cline { 2 - 3 } UB8521 & $2 \mathrm{a}$ & $0.87 \pm 0.09$ & $41^{\circ} \mathrm{C}$ \\
UB8524 & $2 \mathrm{~b}$ & $0.18 \pm 0.06$ & $0.90 \pm 0.12$ \\
UB8525 & 3 & $0.13 \pm 0.03$ & $0.36 \pm 0.15$ \\
&
\end{tabular}

in L-broth containing $\left[{ }^{14} \mathrm{C}\right] \mathrm{GlcNAc}$ and chloramphenicol $\left(150 \mu \mathrm{g} \mathrm{m} \mathrm{m}^{-1}\right)$ at $37^{\circ} \mathrm{C}$ and $41{ }^{\circ} \mathrm{C}$. Differences in wall thickening between the parent strain and some mutants were found (Table 3). The PBP 2a mutant had almost the same thickening activity as the parent strain at $37^{\circ} \mathrm{C}$ and $41^{\circ} \mathrm{C}$ (Table 3). On the other hand, PBP 2b and PBP 3 mutants showed very poor wall thickening activities when compared with the parent strain, especially at $37^{\circ} \mathrm{C}$ (Table 3 ).

\section{Degree of peptidoglycan cross-linking}

In order to estimate the degree of cross-linking in vivo, $\left[{ }^{14} \mathrm{C}\right] \mathrm{GlcN}$ Ac was added to various cultures of $B$. subtilis growing at $37^{\circ} \mathrm{C}$. Cells were treated with TCA and the hot acid precipitates 
were acetylated prior to lysozyme treatment since bacilli may contain $N$-nonsubstituted glucosamine residues, and hence are resistant to lysozyme (Araki et al., 1972). Lysozyme digests were analysed using descending paper chromatography. Bacillus megaterium has basically the same peptidoglycan structure as $B$. subtilis (Wickus \& Strominger, 1972); by comparing the published order of fragments on the chromatograms containing material from $B$. megaterium (Wickus \& Strominger, 1972) with that obtained in this work for $B$. subtilis, the digestion products (uncross-linked and cross-linked) from walls of $B$. subtilis were identified. The extent of cross-linking was calculated as the ratio of cross-linked to uncross-linked material (values given are means \pm SD for two experiments with three replicas in each case). The PBP 2a mutant showed a slightly higher degree of cross-linking $(1.68 \pm 0.06)$ and the PBP $2 b$ mutant showed a slightly lower degree of cross-linking $(1.35 \pm 0.02)$ than the parent strain $(1.47 \pm 0.08)$. On the other hand, the degree of cross-linking in the PBP 3 mutant $(1.43 \pm 0.09)$ did not differ significantly from the wild-type parent strain $(1.47 \pm 0.08)$.

\section{DISCUSSION}

When the affinities of a wide range of $\beta$-lactams for $B$. subtilis PBPs were examined we found that most of the antibiotics bound to more than one PBP at growth inhibitory concentrations (data not shown). Because we were unable to inhibit individual PBPs by $\beta$-lactam antibiotics, it was not possible to infer by this means whether certain individual PBPs have particular roles in the growth of $B$. subtilis. Therefore, as an alternative approach, we isolated several NTGinduced mutants that exhibited defects in a single PBP.

Five mutants were isolated, three of which were defective in PBP 2a (UB8521, UB8522, UB8523), one defective in PBP 2b (UB8524) and one defective in PBP 3 (UB8525) (Figs 1-5). Preliminary examination of the mutants suggested that PBP 2a mutant strains UB8522 and UB8523 were physiologically active in spite of the apparent modification of their PBP 2as. For instance they grew normally in L-broth at different temperatures and showed no morphological alterations (data not shown). Therefore, only mutants UB8521, UB8524 and UB8525, and not UB8522 or UB8523, were further examined. Since NTG can cause multiple gene mutations (Guerola et al., 1971) we attempted to isolate PBP revertants, to try to ensure that the observations we made were due to PBP mutations and not other mutations. We were unable to isolate revertants of the PBP 2b mutant UB8524. However, spontaneous revertants of the PBP 2a and PBP 3 mutants were obtained which had normal PBP profiles and normal susceptibilities to $\beta$-lactams (data not shown).

The three mutants UB8521 (PBP 2a), UB8524 (PBP 2b) and UB8525 (PBP 3) displayed alterations in cellular morphology when compared to the parent strain (Figs 6 and 7). Generally these morphological alterations were not temperature dependent even for the PBP 2a mutant (UB8521), which possessed a PBP 2a thermolabile for penicillin binding (Fig. 1). The PBP 2a of mutant UB8521 is therefore physiologically defective at various temperatures. Abnormal morphology of the PBP mutants studied here might be related to one or more of the following: (1) altered peptidoglycan content, (2) differences in the extent of peptidoglycan cross-linking, or (3) differences in the geometry of cross-linking. Alteration in the peptidoglycan content could result from overall changes in peptidoglycan synthetic activity and/or altered wall thickening activity: evidence for both types of alteration was obtained. The PBP 2a mutant had a higher peptidoglycan synthetic activity than its parent strain, whereas the opposite applied to the PBP 2b mutant. The PBP 3 mutant also had a higher peptidoglycan synthetic activity than the parent strain after growth at $41^{\circ} \mathrm{C}$. With respect to wall thickening activity, the PBP $2 \mathrm{~b}$ and 3 mutants were defective when compared to the parent strain. The suggestion that altered peptidoglycan thickening may contribute to cell shape distortion in PBP $2 \mathrm{~b}$ and 3 mutants is consistent with the abnormal thickening of peptidoglycan reported for penicillin-induced helical growth in Bacillus licheniformis (Highton \& Hobbs, 1971), and observations on a B. subtilis mutant with irregular morphology (Fan et al., 1972).

Differences in the extent of cross-linking, which might also contribute to abnormal cell shape, were noticed in the PBP $2 a$ mutant, where cross-linking was elevated, and in the PBP 2b 
mutant, where the level of cross-linking was less than that shown by the parent organism. Although we have not specifically examined peptidoglycan geometry or orientation in the mutants described here, alterations at this level could also contribute to modified cell shape. Some evidence suggests that when $B$. subtilis assumes a helical shape, the glycan backbone lies in a helical orientation (Mendelson et al., 1984). Because the peptide side chain projecting from a glycan chain may be cross-linked to a neighbouring peptide side chain of another glycan strand, it is possible that the angle of cross-linking of these peptide side chains may create tension on the glycan backbone, producing a helical shape. The possibility that side chains may be linked at different angles in a Gram-positive bacterium like $\boldsymbol{B}$. subtilis is not surprising since spatially complex multi-layers of peptidoglycan exist. The angle of cross-linking of the peptide side chains may be altered if a PBP is defective or absent.

Our results indicate that mutations affecting the nature of expression of PBPs $2 a, 2 b$ and 3 lead to pleiotropic effects on peptidoglycan metabolism that in turn produce abnormal cellular morphology. Although we have not been able specifically to assign individual functions to these PBPs, none appears to be exclusively involved in septum formation because the mutants did not form filaments. However, the possibility remains that PBP $2 b$ may nevertheless play a role in septum formation because it is enriched in $B$. subtilis minicells (primarily former cell septa) (Shohayeb \& Chopra, 1985), and Neyman \& Buchanan (1985) have shown enrichment of PBP $2 \mathrm{~b}$ at the time of septum formation in germinating spores of $B$. subtilis. Therefore, in the PBP 2b mutant described here (UB8524), the function of PBP 2b in septum formation could be replaced by another $P B P$.

All isolated PBP mutants were either hypersensitive or resistant to different $\beta$-lactams at various temperatures (Table 1 shows susceptibilities at $37^{\circ} \mathrm{C}$ ). Hypersensitivity of a PBP mutant may be due to the replacement of the function of a defective PBP by another PBP, the latter having a higher affinity for $\beta$-lactams (e.g. see Suzuki et al., 1978). Resistance may be due to the decreased affinity of a modified PBP to the tested $\beta$-lactam (Reynolds, 1984). In the context of the present studies both suggestions need further examination, but changes in the susceptibility of a PBP mutant imply that the modified PBP may be a killing target (Buchanan \& Strominger, 1976; Suzuki et al., 1978). Therefore, our data suggest that PBPs 2a, $2 \mathrm{~b}$ and 3 are killing targets. The fact that these three PBPs were also found to be essential for shape determination and peptidoglycan synthesis confirms this suggestion. Our conclusions regarding PBP $2 \mathrm{a}$ and $2 \mathrm{~b}$ as killing targets are supported by data from other groups (Klepp \& Strominger, 1982; Waxman \& Strominger, 1983). However, our conclusion that PBP3 is a killing target is at variance with that of Buchanan \& Strominger (1976), who excluded this possibility. In general, inhibition of more than one target PBP is usually required to cause bacterial cell death (Tomasz, 1983). Our results for $B$. subtilis agree with this general statement since none of the individual PBP mutations was lethal.

M. S. gratefully acknowledges receipt of a research scholarship from the Egyptian Ministry of Education. We also thank M. Basker and J. Warrack, of Beecham Pharmaceuticals Research Division, for help with scanning electron microscopy.

\section{REFERENCES}

Adelberg, E. A., Mandel, M. \& Chen, G. C. C. (1965). Optimal conditions for mutagenesis by $N$. methyl- $N^{\prime}$-nitrosoguanidine in Escherichia coli K12. Biochemical and Biophysical Research Communications 18, 788-795.

ARaki, Y., Nakatani, T., Nakayama, K. \& Ito, E. (1972). Occurrence of $N$-nonsubstituted glucosamine residues in peptidoglycan of lysozyme resistant cell walls from Bacillus cereus. Journal of Biochemistry 247, 6312-6322.

Blumberg, P. M. \& Strominger, J. L. (1972). Isolation by covalent affinity chromatography of penicillin-binding components from membranes of Bacillus subtilis. Proceedings of the National Academy

of Sciences of the United States of America 69, 37513755.

Buchanan, C. E. \& Strominger, J. L. (1976). Altered penicillin-binding components in penicillin-resistant mutants of Bacillus subtilis. Proceedings of the National Academy of Sciences of the United States of America 73, 1816-1820.

Chamberlin, J. P. (1979). Fluorographic detection of radioactivity in polyacrylamide gels with the water soluble fluor, sodium salicylate. Analytical Biochemistry 98, 132-135.

Fan, D. P., Beckman, M. M. \& Cunningham, W. P. (1972). Ultrastructural studies on a mutant of Bacillus subtilis whose growth is inhibited due to 
insufficient autolysin production. Journal of Bacteriology 109, 1247-1257.

Frere J. M. \& JORIS, B. (1985). Penicillin sensitive enzymes in peptidoglycan biosynthesis. CRC Critical Reviews in Microbiology 11, 299-396.

Guerola, N., Ingraham, J. L. \& Cerda-Olmedo, E. (1971). Induction of closely linked multiple mutations by nitrosoguanidine. Nature New Biology 230 , 122-125.

Herbert, D., Philipps, P. J. \& Strange, R. E. (1971). Chemical analysis of microbial cells. Methods in Microbiology 5B, 209-344.

Highton P. J. \& HobBs D. G. J. (1971). Penicillin and cell wall synthesis: a study of Bacillus licheniformis by electron microscopy. Journal of Bacteriology 106, 646-658.

Horikawa, S. \& Ogawara, H. (1980). Penicillinbinding proteins in Bacillus subtilis. The effects on penicillin-binding proteins and the antibacterial activities of beta-lactams. Journal of Antibiotics 33, 614-619.

KLEPP, G. \& STROMINGER, J. L. (1979). Studies of the high molecular weight penicillin-binding proteins of Bacillus subtilis. Journal of Biological Chemistry 254, 4856-4862.

Klepp, G. \& Strominger, J. L. (1982). Penicillinbinding proteins in Bacillus subtilis mutants. Antimicrobial Agents \& Chemotherapy 21, 979-983.

Mendelson, N. H., Favre, D. \& Thwaites, J. J. (1984). Twisted states of Bacillus subtilis macrofibers reflect structural states of the cell wall. Proceedings of the National Academy of Sciences of the United States of America 81, 3562-3566.

Mertens, G. \& ReEve, J. (1977). Synthesis of cell envelope components by anucleate cells (minicells) of Bacillus subtilis. Journal of Bacteriology 129, 11981207.

Mirelman, D., Yashouv-Gan, Y. \& Schwarz, U. (1976). Peptidoglycan biosynthesis in a thermosensitive division mutant of Escherichia coli. Biochemistry 15, 1781-1790.

Neyman, S. L. \& Buchanan, J. E. (1985). Restoration of vegetative penicillin-binding proteins during germination and outgrowth of Bacillus subtilis spores: relationship of individual proteins to specific cell cycle events. Journal of Bacteriology 161, 164 168.

REYNOLDS, P. E. (1984). Resistance of the antibiotic target site. British Medical Bulletin 40, 3-10.

Shivakumar, A. G., Hahn, J. \& Dubnau, D. (1979). Studies on the synthesis of plasmid-coded proteins and their control in Bacillus subtilis minicells. Plasmid 2, 279-289.

Shockman, G. D. (1965). Unbalanced cell-wall synthesis: autolysis and cell-wall thickening. Bacteriological Reviews 29, 345-358.

Shohayeb, M. \& Chopra, I. (1985). Composition of membranes from whole cells and minicells of Bacillus subtilis. Journal of General Microbiology 131, 345-354.

SPRATT, B. G. (1977). Properties of the penicillinbinding proteins of Escherichia coli K12. European Journal of Biochemistry 72, 341-352.

SPRaTT, B. G. (1983). Penicillin-binding proteins and the future of $\beta$-lactam antibiotics. Journal of General Microbiology 129, 1247-1260.

SuZUKi, H., Nishimura, Y. \& HiRota, Y. (1978). On the process of cellular division in Escherichia coli: a series of mutants of Escherichia coli altered in penicillin-binding proteins. Proceedings of the National Academy of Sciences of the United States of America 75, 664-668.

Tomasz, A. (1983). Mode of action of beta-lactam antibiotics - a microbiologist's view. In Antibiotics Containing the Beta-lactam Structure. Vol. 1, Handbook of Experimental Pharmacology 67, pp. 15-97. Edited by A. L. Demain \& N. A. Solomon. Berlin: Springer-Verlag.

WaXman, D. J. \& Strominger, J. L. (1983). Penicillinbinding proteins and the mechanism of action of beta-lactam antibiotics. Annual Review of Biochemistry 52, 825-869.

Wickus, G. G. \& Strominger, J. L. (1972). Penicillin sensitive transpeptidation during peptidoglycan synthesis in cell-free preparations from Bacillus megaterium. II. Effect of penicillin and cephalosporins on bacterial growth and in vitro transpeptidation. Journal of Biological Chemistry 247, 5307-5311. 